\title{
The Focus of College Counselors'Ideological and Political Education for College Students in the Context of the New Era
}

\author{
Zhixin Liu \\ Yingkou Institute of Technology, Yingkou, 115000, China
}

Keywords: Counselors; College students; Ideological and political work

\begin{abstract}
Counselors are the direct organizers and implementers who have the closest contact with college students and undertake the daily education and management of College students. They play an active and irreplaceable role in the ideological and political education of College students. How to adapt to the educational requirements of the new era and improve the ideological level of college students through ideological guidance and educational practice is an important issue. This paper studies the role optimization and means innovation of College counselors, and puts forward several gravity points to do well in college students' ideological and political work.
\end{abstract}

\section{Introduction}

The Nineteenth National Congress of the Communist Party of China declared that socialism with Chinese characteristics has entered a new era, and the corresponding education work has entered a new era. Since the Eighteenth National Congress of the Communist Party of China, General Secretary Xi Jinping has made a series of expositions on the education work, and put forward the requirements of upholding morality and cultivating people, and strengthening and improving the ideological and political work in Colleges and universities. All these constitute the fundamental follow for college counselors to do well in the ideological and political work in Colleges and Universities under the new situation. In this context, we should pay attention to grasp the law of Ideological and political work in Colleges and universities, grasp and follow certain teaching methods, and make great efforts to cultivate new people in the era of national rejuvenation, so that college students can become successors and builders of socialist cause.

\section{New Requirements for College Counselors in the New Era}

General Secretary Jinping's important speech at the National Conference on Ideological and Political Work in Colleges and Universities pointed out the great significance, objectives, main tasks and working methods of Ideological and political work in Colleges and Universities under the new situation. At the National Conference of propaganda ministers in 2018, the mission of propaganda and ideological work to cultivate new people was put forward, which all put forward requirements for college counselors to do well in Ideological and political work in Colleges and universities. The ideological and political education of contemporary college students is closely related to the development of the times. It is an important task for the educational circles in the new era to strengthen the ideological and political education of College students. The state attaches great importance to the ideological and political education of contemporary college students. It requires that we start with strengthening the ideological and political education of college students and cultivate high-quality talents in the new era in line with socialist construction. Colleges and universities have made various explorations and practices to constantly strengthen ideological guidance and correctly guide the world outlook, values and outlook on life of College students.

Counselors shoulder the important responsibility of training and educating people. They are a challenging undertaking. They put forward high requirements for the White-body quality and practical working ability of counselors. In addition to the new requirements of the new era, with the continuous development of China's economic system and social situation, there are conflicts between social trends of thought and interests. Under such a social background, college students 
will be in a vague and confused situation. At this time, college counselors should adapt to the development of the situation in time and actively open a new chapter of Ideological and political education, so as to strengthen the ideological and political education of Li De Shuren. As the direct executor of Ideological and political education, college counselors need to set a good example in knowledge structure, ability level, language expression ability, appearance and posture, moral quality, psychological quality and so on, and play a good role in guiding education.

1) Improve the knowledge structure of Ideological and political education for freshmen. College students'ideological and political education is complex and professional, which requires counselors to have strong professional knowledge and practical ability in pedagogy, management, psychology, history, vocational counseling and student affairs management. They should be familiar with the ideological and psychological characteristics of freshmen and master the general laws, methods and basic knowledge of Ideological and political education and management of freshmen. Knowledge. Counselors should strengthen the improvement and learning of relevant knowledge, and strive to create a professional, highly skilled and well-knowledgeable image of modern freshmen counselors.

2) Have excellent ideological and political quality and noble moral quality. Ideological and political quality is very important. It requires counselors to constantly pursue progress in ideology, to have a profound understanding, understanding and understanding of the Party's line, policy, policy and educational policy under the new situation, to always support the Party's line, policy and policy in practical work, and to maintain a high degree of consistency with the Party Central Committee politically, ideologically and in words and deeds, with a high degree of political sensitivity. Political insight and political discrimination. We should pay attention to the cultivation of good personal character, correctly handle the relationship between individuals and the state, the collective and others, and play an exemplary role in Ideological and political education.

3) Stable and healthy psychological quality. The positive and healthy psychological quality of counselors is the precondition for their participation in college students' mental health education. Counselors should grasp the professional knowledge of psychology, have their own unique opinions on the field of psychology, improve their psychological quality, make every effort to understand the ideological and psychological characteristics of freshmen, master the common psychological problems of freshmen and the law of development of this special group, communicate with students with psychological problems in an equal, respectful and honest manner, and open the hearts of freshmen. Help them out of their mental predicament.

4) Create positive personality charm. Counselors should possess the personality charm of being positive, willing to work, regardless of gains and losses, and selfless dedication. They can promote the ideological and political education of College students, guide them to adjust their thinking, overcome utilitarianism, and learn to deal with the interests between the state, the collective and the individual consciously and correctly.

\section{The Role of Effective Counselors in College Students' Ideological and Political Work}

Counselors are an important part of the teaching and management teams in Colleges and universities. They have the dual identities of teachers and cadres, and are the backbone of Ideological and political education for college students. For a long time, the work of College Counselors in Colleges and universities is quite complicated, and there are also problems of multi-department management and multi-task assignment. It can be said that the work of counselors involves all aspects of college students' learning, thinking, life, style, social practice and even the family. There are thousands of lines above, and eventually they are all worn on the needle of counselors. It is necessary to change this situation so that university supervisors can devote themselves to ideological and political work. To accurately grasp the orientation of counselors, it is necessary to make it clear that the primary task of counselors is to integrate the socialist core value system into the ideological and political education of College students, to guide students to establish correct world outlook, outlook on life and values, and to carry out the fundamental task of cultivating morality and cultivating people.

1) College freshmen counselors are "confidants". In the ideological and political education of 
freshmen, counselors should have a comprehensive and profound understanding of the freshmen's age structure, knowledge structure and ideological and psychological conditions. In the process of work, we should always pay attention to the use of communication methods, hold more symposiums to exchange feelings and opinions, care about them as bosom friends, and encourage them. In this kind of subtle influence, ideological and political education will go deep into the hearts of new students and play a multiplier effect with half the effort.

2) The freshman counselor is the freshman's "server". Counselors should be people-oriented in Ideological and political education and provide high-quality services in learning, scientific research, life, practice and employment. Starting from the actual needs of freshmen, we should give full play to the service function of counselors, create a positive, warm and harmonious working atmosphere, and create a good cultural environment.

3) The freshman counselor is the "model" of the freshman. Counselors should set an example, be a teacher, set an example, take the lead, show their personality charm, and conquer the new students with their personality strength. Counselors should pay attention to the civilized cultivation of their own behavior, and influence students with their own integrity, modesty, fairness and integrity.

4) The freshman counselor is the "life tutor" of the freshman. As the undertaker of Ideological and political education for freshmen, counselors have the responsibility and obligation to guide college students out of their lost ways and confusion, guide them to overcome difficulties and overcome themselves. Counselors can compare their own growth experience with students' growth, close the distance between each other in equal sharing and help, guide them imperceptibly, and really play the role of "life mentor".

\section{Important Points and Strategies of Ideological and Political Work for College Students}

Ideological and political work in Colleges and universities is the work of being a person. Relatively speaking, college students are the most active group in the social group, and they are also the time when values and world outlook and outlook on life are shaping. If we do not grasp the appropriate methods and means, it will be difficult to achieve twice the result with half the effort. Therefore, this paper holds that college counselors should play a good role in guiding the authors, focusing on the core values of socialism through education, changing educational ideas, focusing on education, optimizing teaching mode, and related to the growth of College students, so as to achieve the goal of cultivating new people in the era of all-round development of morality, intelligence, sports, beauty and labor.

1) Put the socialist core values throughout the ideological and political education. Core values have the function of gathering people's hearts and strength. It plays a decisive role in our country's efforts to realize the Chinese dream of great rejuvenation of the Chinese nation. College students, as the hope and future of the country, must become the focus of education, and guide them to be patriotic, party-loving, people-loving and useful to society. In specific work, we should integrate socialist core values into teaching materials, classroom, school culture and other aspects. For example, public service advertisements of core values can be posted in classrooms, playgrounds, dormitories and other places, and they can be guided to strengthen their ideals and beliefs in communicating with college students and joining the Party during the inspection. Ideological and political assessment can be regarded as an important indicator, and so on.

2) Release the counselor from the cumbersome office. Ideological and political work should be placed in a more important position, and the ideological and political level of students should be taken as an important part of the work of College counselors. To implement the "Opinions on Further Strengthening and Improving the Ideological and Political Education of College Students", teachers should adhere to correct political concepts and truly understand, use and believe in the content of Marxism. To strengthen the training of counselors, we can build a good atmosphere for the construction of counselors team by building a training and research base for college counselors.

3) Emphasis should be laid on strengthening the ideological and political work of college students by means of network education. According to the survey data of China Internet Information Center, among the 26.5 million netizens in China, 6.8\% are $18-24$ years old, and $84 \%$ 
are college students. This is a very large group. We should make full use of the technology of network resources to open up new fields of education, combine the traditional advantages of Ideological and political education in Colleges and universities, realize the limitations of spacing and time, and achieve the timeliness, modernization and scientificalization of Ideological and political education in Colleges and universities.

4) Adhere to the fundamental principle of student-oriented. People-oriented is the core of scientific development concept. Specifically speaking, the work of college counselors is to establish the working concept of "taking the growth of students as the basis", adhere to the fundamental principle of "taking students as the basis", emphasize students' individual differences, take students as the core and fundamental principle of counselors' work, and cultivate qualified builders and reliable successors of the cause of socialism with Chinese characteristics.

5) Innovating teaching content and enriching ideological and political education resources in Colleges and universities. Ideological and political work is historic. We should combine the physical and mental characteristics of contemporary college students, develop attractive and inspiring curriculum resources, integrate educational resources inside and outside the classroom, inside and outside the campus, online divination, domestic and foreign. In the process of guiding students to explore the great historical journey of national rejuvenation, we should promptly answer the social hot spots and focus, timely answer the concerns and doubts of young students, and let students feel the ideological and political issues. Classroom size is only related to national games, but also to personal growth and talent.

6) Grasp the needs of students and guide them according to circumstances. College counselors work in the front line of student work. They should conduct in-depth and meticulous ideological dynamic tracking research to understand the concerns and confusion of College students. We should try our best to grasp the students' ideological trends, listen to their voices, understand their thoughts and needs, and make clear the confusion they are facing in the process of their growth. At present, our country is in the period of social transformation, and various contradictions and problems are more prominent. We should guide college students to correctly understand social phenomena and social problems.

\section{Conclusion}

College counselors are the main undertakings of Ideological and political work in Colleges and universities. Under the new task of the new era, college counselors should not only renew their knowledge structure and optimize classroom teaching, but also put the specific requirements of strengthening and improving college ideological and political work in the new era through all aspects of their work. Only in this way can we undertake the mission well.

\section{References}

[1] Liu P. Opportunities and Challenges of the Ideological and Political Education for College Students in New Era[C]// International Conference on Economics. 2015.

[2] Zhang Y. Research on the Innovation of College Students' Ideological and Political Education in Big Data Era [J]. Journal of Jiamusi Vocational Institute, 2017(icicee).

[3] Williams J. Study on the Innovation in Ideological and Political Education for College Students in the Context of Internet [J]. Journal of Huaihai Institute of Technology, 2011.

[4] Yu K. Research on Carrying out the Ideological and Political Education by College Counselors Based on WeChat in the New Era [J]. Management \& Technology of SME, 2018.

[5] Qiao H, Tan L . Development and Application of Management Information System for College Students[C]// 2018 International Conference on Intelligent Transportation, Big Data \& Smart City (ICITBS). IEEE Computer Society, 2018. 